Agnieszka Ilwicka

University of Wrocław, Poland

\title{
Grand Illusion? \\ The Phenomenon of Jewish Life in Poland after the Holocaust in Lower Silesia
}

\begin{abstract}
The Jewish Life in Poland inLower Silesia began with the end of World War II. Survivors from the local concentration camp in Gross Rosen created the first Jewish committee and, with German Jewish survivors, started a new chapter in the post war history of Lower Silesia. The fact that only $10 \%$ of the Jews from the whole population overcame the extermination should be borne in mind. There is a related branch of research that seeks to determine how long Jewish life continued in Europe, where and under what conditions. In the last few years, we have become aware of the extent to which Jews actually built new possibilities after World War II in Poland, 1945-1968. In fact, the prevailing popular image of post-war Jewry is a simplistic one that divides the Jewish population into basic groups: the assimilated Jews of Russia; the "Jewish Jews" of Poland and other western areas, annexed to the Soviet Union, who sought to preserve at least some aspects of Yiddishkayt (Jewishness); and the traditional Jews, who remained devout.

In the period of 1945-1950, the Jews created the most important center of Jewish Life in Europe, in terms of culture, industry, education and intellectual life. A stabilization period of the Jewish settlement began with the autumn of 1946. The softening of emigration rules and the closure of the Polish borders in the winter of 1947 helped Jews fully concentrate on the Jewish life in Poland. At that time, political, social, economic and cultural activities continued to be carried out on a large scale. In 1946, 16,960 Jews were registered in Wrocław. With the change of the policy towards the Jewish community by the communist government of Poland, the Jewish settlement in Wrocław slowed down and eventually, at the beginning of the 70's, Jewish life in the Lower Silesia disappeared from the cultural map of the local landscapes.
\end{abstract}


Even though some of the Jewish settlers remained in the Lower Silesia to continue Jewish life in this territory, the community never became as strong and influential as it was at the beginning of the settlement.

\section{Keywords}

Polish Jews, German Jews, communism, Holocaust, survivors of the Holocaust, Lower Silesia, Poland, Jacob Egit.

\section{Survive: and what next?}

In early May 1945 there were still about 10, 000 Jews in the camps. Breslau (today Wrocław) was surrounded by the Soviet Army; the fighting could be sensed in the camps and the prisoners felt that freedom was near. After the liberation, the Jewish survivors in Reichenbach (today Dzierżoniow) formed a committee headed by Szymon Bialicki, a former union activist from Dąbrowa. Members of the committee, ex-prisoners of the Gross-Rosen concentration camp, sent a telegram to Warsaw informing the Central Committee of Jews in Warsaw, that they were alive and free. This information gave enough impact to create a plan for rebuilding the Jewish way of life after the Holocaust. On $17^{\text {th }}$ May 1945 Jacob Egit, a communist, and Yitzhak Zuckerman, a Zionist, came to Dzierżoniów for three days to assess possibilities for the Jewish life in post-war Poland ${ }^{1}$. They discussed the future of the Jews in Poland. Zuckerman, a ghetto fighter in the Warsaw ghetto uprising in 1943, did not want to stay in Poland; in fact he left to Palestine in 1946. But Jacob Egit was enthusiastic about the new possibilities. He convinced Jews to start their new life in the Lower Silesia ${ }^{2}$.

Many survivors wished to emigrate, to leave the war experience behind and to escape from the country over which anti-Semitism hovered. The fear concerning their lives was still very strong, even many years after the war. Current information states that about 2000 Jews were killed in the first years

1 J. Egit, Grand illusion, Toronto 1991, p. 21.

2 This history was confirmed by Jonas Turkow, journalist and an actor, in his memoirs; Turkow was one of the settlers who also worked after the Holocaust for the Yiddish radio in Lublin and later for the Jewish theatre in Lower Silesia. See Jonas Turkow, Nokh dem bafrayung (Yiddish), Buenos Aires 1959, p. 56. 
after World War II in Poland ${ }^{3}$. On the other hand, even today it is difficult to estimate the number of Polish Jews who went into hiding during the Holocaust and those who survived the war ${ }^{4}$.

Why was the idea of a Jewish settlement in Poland after the war in Lower Silesia so attractive to some people? Why did Jacob Egit not promote the idea of the settlement in the Warsaw district? An important fact about Lower Silesia was that, in the summer of 1945, this region seemed free of antiSemitism and proved friendly for Jewish settlers; it was different than in the other parts of Poland. Also, in Lower Silesia, there remained a small number of Jews, approximately 2000. The temperature and climate of Lower Silesia was ideal for agriculture, with forests covering thirty-five percent of the area. The larger cities were Wrocław (then Breslau), Wałbrzych (Waldenburg), and Legnica (Liegnitz). All centers, large and small had electricity and gas heating. This was important specifically at the beginning of the settlement as, in the ruins of Warsaw, beginning a new life was impossible. The homes, clothes and food left behind by the Germans expelled from Lower Silesia, were distributed to the Holocaust survivors and Poles who, immediately after World War II began settlement in the new territories. Factories, farms and businesses which were intact also became the property for survivors and Poles. The whole region was cultivated and industrialized. Before the war, a significant percentage of the male population was engaged in coal mining. In addition to coal, there were other rich mineral deposits in Lower Silesia such as nickel, magnesium, potash, copper, silver and gold. Rich in natural resources, Lower Silesia had developed variegated industries which made it a major economic center in textile mills, foundries, breweries and lumberyards. This helped Polish and Jewish settlers to find employment. Importantly, most of this territory was untouched by the war, except for the city of Wrocław (Breslau).

3 Następstwa Zagłady Żydów. Polska 1944-2010, Ed. F. Tych, M. Adamczyk-Garbowska, Lublin 2011, p. 17-18.

4 Historians estimate fifty thousand. In Warsaw, approximately fifteen thousand Jews were sheltered by up to two or three thousand Polish families. If we take into account that these families acted with the knowledge and approval of their nearest relatives, we reach the conclusion that at least ten to fifteen thousand Polish families in Warsaw were helping to hide the Jews. Unfortunately, even today some people are afraid to testify that they helped Jews during World War II. This is a consequence of the post-war anti-Semitism in Poland. 


\section{From ashes and fire: beginning of the Jewish settlement in Poland after the Holocaust in Lower Silesia}

Wrocław (Breslau) for many years was a symbol of the 'Jewishness' in Lower Silesia because of the famous Rabbinical Seminary, destroyed during World War II. After the war, some signs of former Jewish life still remained in Wrocław - the white Stork synagogue, a community building on Włodkowica Street and the Jewish cemeteries. Most of the Lower Silesian Jews before the war were merchants but some of them owned factories and operated various businesses. The Jewish intelligentsia was assimilated with the German speaking community which was the reason of the post-war discrimination of this community towards those who survived the war in Lower Silesia.

The first settlers in the territory of Lower Silesia were ex-prisoners from Gross-Rosen concentration camp, which was the largest extermination camp and crematorium in this part of Germany. The torture, the forced labor and suffering was the same as in Auschwitz and Majdanek. Inmates worked under horrendous conditions, breaking up stones for a new highway. Like in another camps, as soon as Jews were too weak to work, they were sent to the crematoria. There were also camps near Reichenbach, Waldenburg, Klempmendorf, Strigoff and Grayditz for Jewish prisoners. In Bielawa, in the textile factory, 'Flechtner' was a camp for Jewish girls with another one in Grossmoslovitz near Breslau. Thousands of prisoners died of typhus and other diseases. The women's camp in Ludwigsdorf where Germans built a large munitions factory had young Jewish girls and women working there with picric acid, phosphoric acids and the death gas cyclone without masks or protective garments. Shortly, because of the chemicals, they became sterile.

After the Holocaust Jews in Poland felt loneliness and despair ${ }^{5}$. Tired and exhausted from their war experiences, they desperately needed to find a new sense of life. Most Jews were coming back to their homes, trying to find family and friends. The hope to find someone alive was the most powerful motivation to return to the place where home had been before World War II. Often these searches were met with failure. Jacob Egit, the chairman of the

The dehumanization of Nazi camps in Poland and Germany has been well documented and researched by scholars in Europe, America, and Israel. But the most illuminating are personal testimonies of Tadeusz Borowski, Primo Levi, and Elie Wiesel. See P. Levi, If This Is a Man, New York 1959; E. Wiesel, Night, Dawn, the Accident: Three Tales, New York 1972; T. Borowski, This Way for the Gas, Ladies and Gentlemen, New York 1976. 
Jewish community in Lower Silesia since 1945, wrote: "How disappointed were those, who were coming back to their old houses! No dearest people, no friends; the home was destroyed and even on the cemetery was no tombstone"

In June 1945 the concept of the Jewish settlement in Western Poland was presented by Jacob Egit to the Polish authorities as well as to the Central Committee of Jews in Poland. On 17 th June 1945 The Department of the Public Administration (Ministerstwo Administracji Publicznej) agreed with this plan ${ }^{7}$. Nevertheless, the government of Poland had bigger ideas for the settlement in this region as well as Pomerania and Masuria; in fact the Jews presented only a small part of this project, about $200,000^{8}$. In this context it is important to keep in mind that, again, Polish Jews were a minority. This gave a strong impact for future relations between Jews and Poles.

Thus, the idea of a settlement came into existence in the summer of 1945. The settlers organized the Jewish Committees wherever there were groups of Jews. Jewish and non-Jewish victims of the World War II were all in a terrible condition. "When thirteen months ago we were taking our first steps as the recently liberated, people looked at us like dreamers who dreamed..." - wrote Jacob Egit in July 1946 on the front page in the newspaper "New Life". At the beginning of May 1945 only 42,662 Jews were registered with all the Jewish Committees in Poland. The first Jewish committee in Lower Silesia was established on $17^{\text {th }}$ June 1945 and until 1946 settled in Dzierżoniów (Reichenbach). The establishment of the Jewish Committees was a result of basic needs - combating illness, poverty and homelessness. Each committee played an important role for the Jewish community after the war. This was the place where everyone who wanted to be registered as a Jew came. Also, in the beginning, it was only in the Jewish Committees that anyone could ask if family members, spouses or friends had survived. In fact, the Committees became the centres for the Jewish society. The main goal of its activity during the first period after the war was the care of ill and suffering survivors.

6 J. Egit, Rok życia żydowskiego na Dolnym Ślasku, jednodniówka Nowe Życie, 15 VII 1946; in many places Jews were expelled from their homes by new Polish habitants.

7 Sz. Bronsztejn, Z dziejów ludności żydowskiej na Dolnym Śląsku po II wojnie światowej (History of the Jewish community in Lower Silesia after World War II), Wrocław 1993, p. 13.

8 The Jewish Historical Institute, Wydziat Produktywizacji CKŻP, sign. 11, Okólnik 6 VI 1945.

9 J. Egit, Rok życia żydowskiego na Dolnym Ślasku. Nowe Życie. Jednodniówka. Trybuna Wojewódzkiego Komitetu Żydowskiego na Dolnym Śląsku, Wrocław 1946 no 1, p. 1. 
Especially for the victims of concentration camps it was needed to organize special care and money, as well as places to live and work.

In August, the Central Committee of Jews in Poland began the propaganda action to invite Jews for the settlement in the territory of Lower Silesia. This, so called, 'rediscovered territory' was presented as an ideal area for the rebirth of Jewish life in Poland, after the Holocaust. It was only in this region that they did not face any problems regarding the houses and farms, a common difficulty in other areas such as Lubelszczyzna, Mazowsze or Kielecczyzna. Moreover, in Lower Silesia new settlers could apply for an apartment, work place or farm. Everything seemed easier than in the other parts of Poland. Some Jews observed that Lower Silesian Jewish Committees were less bureaucratic than the others. People experienced here - especially at the beginning of the settlement - a friendly attitude. This was very important, at the time, when newspapers published stories every day about Jews murdered by Poles in Podhale, Kielecczyzna, Warsaw or the surrounding area. The Polish historian, Lucjan Dobroszycki, announced in 1973 that he had "analysed records, reports, cables, protocols and presscuttings of the period to anti-Jewish assaults and murders in 115 localities" where approximately 300 Jews had been killed. Peysekh Novik, a wellknown journalist and author of many books, from May 1946 until January 1947, travelled throughout Europe visiting many countries i.e. France, Czechoslovakia, Poland, the USSR, Germany and England. The goal of his travels was to familiarise himself with the situation in Jewish communities. In 1946, he spent three months in Poland. In his reports, published in New York in 1952, in the book 'Oyrope: tzvishn milkhome un sholem rayzebilder, batrachtungen' (Europe: Between War and Peace) he described Lower Silesia enthusiastically, seeing here the largest chance for a rebirth of Jewish life in Poland after the Holocaust. The following text is a fragment translated from this book where he described his impression about the Jewish Life in Lower Silesia:

"A New Jewish Home: Lower Silesia

The first Jewish committees in Poland were established on the 10th May 1945, one day after the end of the war, when fighting was still going on in neighbouring Czechoslovakia. The energetic and enthusiastic leader of the Provincial Jewish Committee - Jacob Egit - came here as a soldier with the Polish brigades. In Warsaw, he received, from the Central Jewish Committee, 
the authority to build a new Jewish centre on the ashes of the old lower Silesian Jewish settlement. The first Jewish child in Lower Silesia was, in fact, Egit's daughter, who lived for three and a half years in hiding with the Poles, along with her mother, grandfather, and other Jews (twelve in total). Now, in Lower Silesia, there are thousands of Jewish children: in Jewish Children's Homes, schools, preschools.Arrivals in Wrocław (Breslau), where the Provincial Jewish Committee is located, saw a wagon factory quickly appear, the biggest in Poland and one of the biggest in Europe, housing a few hundred Jewish workers. Textile factories in, among other places, Rychbach and Bielawa, employed almost two thousand Jewish textile workers. In the coal centre, Wałbrzych (Waldenburg), around 800 Jewish miners worked. A new type of Jewish worker was emerging in Lower Silesia (...). This expansive industrial infrastructure combined with the fact that the Germans were slowly leaving Lower Silesia (where they could not be immediately replaced, others were trained for their positions) created, literally, limitless possibilities for a Jewish settlement. It was correct to direct the majority of Jewish repatriates from the Soviet Union to this region. However, if not for the talents, enthusiasm, and sacrifice of local activists - catastrophe could have occurred. In a very short time 80,000 Jews arrived there. Accepting and accommodating such a number demanded immense resources - and these were lacking. When American aid began reaching here by the end of June 1946 - the repatriation was almost over. It was only due to the help of the government and its resources that a catastrophe was averted, and thanks to the fact that it was possible to come to the German home and say "make some room!".

The insufficient infrastructure for accommodating repatriates lent itself to many Jews leaving the area.

Jewish settlements in Lower Silesia were concentrated in Wrocław, Rychbach, Bielawa, Wałbrzych, Legnica, Kłodzko and Jelenia Góra. These were industrial centers. Jews, however, lived in 53 cities and towns in Lower Silesia, settled on farms, and also in the vicinity of health resorts.

In Rychbach there was a tight-knit Jewish neighborhood, where Yiddish songs reverberated until late at night. Here a Jewish theatre had its stage, and cultural life was deeply rooted. Jewish newspapers appeared in Lower Silesia. There was a thick web of Jewish associations, schools, cultural centres, libraries, drama circles, a mobile People's University functioning, and a theatre. On the walls of Rychbach, and many other cities, one could 
find many Jewish posters announcing performances and talks. A small part of Jewish life from old Poland, healthy Jewish life, had been resurrected there... (...)".

On the one hand, Lower Silesia seemed to be a Jewish Promised Land in Poland. On the other, it was a dangerous, unknown territory. In addition, Wrocław, the biggest centre for the Jewish culture in Lower Silesia, was, in 1945, the city of ruins; the city was dirty and filled with signs from Germans who lived there over a hundred years.

Novik visited Poland and Lower Silesia in 1946. He did not witness the beginning of the Jewish Settlement in Lower Silesia, especially in Wrocław. In fact, in Wrocław survivors saw ruins upon their arrival. In this, almost totally, devastated city the chance to get a pre-war apartment was nearly non-existent. At the beginning of the Jewish settlement in Lower Silesia the headquarters of the Voievodshaft Jewish Committee and the centre for the repatriates was established in Dzierżoniów, but soon, Jews moved the important administration, social and cultural institutions to Wrocław. Włodkowica Street in Wrocław became a 'center for the Silesialn Jewry'. The Voievodshaft Jewish Committee, religious congregations and the Jewish Association for Culture were at 7/9 Włodkowica Street in Wrocław. Also under this address was the synagogue with "mikvakh"10 and the headquarters for the main Jewish institutions and political parties, as well as the bureau for ORT, TOZ (the Association for Health) and a kosher restaurant open for the members of the Jewish community. Moreover, on Włodkowica Street were the publishing houses for the Jewish newspapers 'Nidershlezye' and 'New Life'. This street, until 1950, was a centre for the Jewish life and culture in Lower Silesia.

Lower Silesia in the spring of 1946 was still safer than other regions in Poland. In August of 1946 there were already 16,000 Jewish workers in Lower Silesia, mostly in cooperatives. An important part of the 'productiveness' of the Jewish population of Lower Silesia was challenging Jews into agricultural pursuits. The creators of this Lower Silesia wished to build an agriculture community from the remaining kibbutz from Palestine. The first settlers settled near the Karkonosze mountains. Zionists were highly interested in this part of the settlement project because they saw it as an opportunity to prepare the Jews for life in the kibbutz when they would emigrate.

\footnotetext{
${ }^{10}$ Hebrew: מקווה: A ritual bath, used for purpose of ritual immersion in Judaism.
} 


\section{A new type of the Jew}

Among the leaders of the Jewish Settlement in Lower Silesia were Jacob Egit, Abraham Rozenman, Ignacy Kuczyński, Jakub Leszcz and Icchak Turkow-Grudberg. All of them enthusiastically built the background for the Jewish settlement, hoping that it could help to create a culture and national autonomy, and, by doing so, stop outward migration among survivors of the Holocaust in Poland. For most of them the main goal was the creation, in Lower Silesia, of a strong centre for the rebirth of Jewish life. In their opinion, survivors should take responsibility for the resistance to Hitler's plan of 'Judendfrei Europe' - a Europe free from Jews. "We can create a settlement for the millions of Jews in Poland and we can play an important role in the Jewish life in Europe. Hitler's plan of Europe free from Jews cannot be real" - wrote Jacob Egit and this text became a leitmotif for the Jewish settlers"11. 'A Yidisher Yishuv'12, a Jewish Settlement, was presented as the best place to birth and create of the new type of Jew, who 'grounds his future on the base with useful work $^{13}$. The images of the Jew - miner, tram driver, farmer - contradicted the stereotypical pictures of Jews as a community of tailors, shoemakers, religious fanatics who were not able to work physically. Besides the fact that this idea sounds like communist propaganda, the leaders of the Jewish community in Poland truly believed that the Jewish 'productiveness' could minimalize anti-Semitic bias. Naturally, this rhetoric is similar as well to XIX century maskilim $^{14}$ who, like Zionists, wanted Jews to change their qualifications towards the agriculture and other 'useful' things; to change the employment structure of Jews in Poland.

Before World War II, only a relatively small number of Jews, those not connected with Jewish organizations and those with a good education, joined the civil service, the officer corps and the apparatus of the Communist Party ${ }^{15}$. Members of the Jewish community were exhausted by the war and

\footnotetext{
${ }^{11}$ J. Egit, Grand illusion, Toronto 1991, p. 45.

${ }^{12}$ Yiddish name for the Jewish settlement in Lower Silesia.

${ }^{13}$ The Archive of the Jewish Association of Society and Culture, Sprawozdanie Wydziatu Produktywizacji za rok 1946.

${ }^{14}$ Enlightened Jews.

${ }^{15}$ See more about Jews involved into communism pre-war: $\dot{Z} y d z i$ i komunizm, Ed. M. Bilewicz, B. Pawlisz, Warszawa 2000; J. Nalewajko-Kulikov, Obywatel Jidyszlandu. Rzecz o żydowskich komunistach w Polsce, Warszawa 2009.
} 
the Holocaust. They were mainly craftsmen, workers, demobilized soldiers, pre-war tradesmen, teachers, free professionals, students as well as people who had not been able to acquire a profession because of the war. Some of them became journalists and lecturers in schools of higher education. This was a new phenomenon in modern Jewish history. Before the war, as a rule, Jews had no access to the civil service. But after the Nazis failed, the structures of power among society in Poland had been changed. The Jewish community was represented by many political factions that existed in 1945, as well as in the period before the war. Those who had joined the communist movement during the interwar period as a form of generational rebellion or as a protest against the unequal treatment of national minorities now became a representation among the Jewish society, favoured by the communist government in Poland. However, the number of communists who had survived the war was small, and in the initial period after the war when it seized power, the Communist Party experienced an acute shortage of staff. This was also the time of political pluralism. Hence, as Jews signed up to the communists they became more 'visible' in that apparatus.

The activities of the Jewish communists in Poland were moving towards the creation of the secular, modern Yiddish culture ${ }^{16}$. As a result of this they hoped to create a new type of Jewish identity. This idea came from the soviet project, thirty years younger than that of Poland, an experiment of the Yiddish culture intelligentsia. Similar to the USSR, in Poland, the main point of this was to keep the ethnic Jewish identity. In fact, Jewish communists created Jewish institutions, in some cases different from Polish, where at the beginning, the spoken and written language was Yiddish. It is important to stress that, in the USSR, the project of the national cultures embraced all nations living in the territory of the Soviet Union; in Poland only Jews were privileged. Only the Jews were given the cultural autonomy ${ }^{17}$.

The Soviet Union experiment failed. "Jewish communists in Poland were naïve and hoped that in this country [Poland] everything would be different and this difference will influence also the USSR. About this false illusion, so called 'nusekh Poyln', communists were taking care even after 1948, when all

${ }^{16}$ See J. Nalewajko-Kulikow, M. Ruta, Kultura jidysz po II wojnie światowej, in: Następstwa zagłady Żydów. Polska 1944-2010, Ed. F. Tych i M. Adamczyk-Garbowska, Lublin 2011, p. $283-304$.

${ }^{17}$ A. Grabski, M. Rusiniak, Żydowscy komuniści po Holokauście wobec języków polskiego żydostwa, in: Nusech Pojln, Ed. M. Ruta, Kraków 2007, p. 57. 
Jewish political parties were liquidated and the country came into the soviet handcuffs"18.

Monika Brzóstowicz-Klajn, the author of "Nowego człowieka obraz" (The Picture of a New Man), described, in her article, a portrait of 'a new Jewish man'. In her opinion there are several personality traits typical of Jewish communists. Among them, 'a new man' needs to be a part of the crowd because that is the source of power and the feeling of security for others. Collective models of life are also important for the members of the communist community, and individual people identify themselves with the collective identity. The concept of 'a new man' created a 'strong person', someone who is immune to normal human weakness, like Lenin or Stalin's desired image. It is also an asexual type of human who loves people without physical love, which is represented in its work for the collective. August Grabski, a polish historian, offered his opinion of an important role played by the patriotism towards the communist party, which was in no way different for Jewish autonomy from the communist ideology ${ }^{19}$.

Thus, the vision of history propagated by the communists contradicted the model in which Jews were passive continuators of the shtetl's traditional life style. It was consequently criticized, even by Jews. The new type of Jew was strongly connected to the idea of 'produktivizatzye' which means 'usefulness'.

The work of both youth and adults dominated the photographic documentation from Lower Silesia, gathered in the Archive of the Department of Jewish Language and Culture at the University of Wrocław. This subject is also visible in Jacob Egit's memoirs 'Grand Illusion' as well as in his book written in Yiddish and published in 1947, 'Tzu a nay lebn' (Towards the New Life). 'Usefulness' is rooted in modern times. It is connected to the stereotypical picture of the Jew as a 'Luftmensch', a free man, a man of air (meaning: unemployed, often homeless). In the XVIII and XIX century this term was connected to the idea of an agricultural colony. As Marcin Wodziński observed, the plan of 'usefulness' belonged to the social, economical and even moral reforms among the Jewish society ${ }^{20}$.

${ }^{18}$ D. Sfard, Mit zikh un mit andere. Oytobiografie un literarishe eseyen, Jeruzalem 1980, p. 180.

19 A. Grabski, Działalność komunistów wśród Żydów w Polsce (1944-1949), Warszawa 2004, p. 43.

${ }^{20}$ See M. Wodziński, 'Wilkiem orać'. Polskie projekty kolonizacji rolnej Żydów 1775-1823, in: Matzeństwo z rozsądku? Żydzi w spoleczeństwie dawnej Rzeczypospolitej, Ed. M. Wodziński and A. Michałowska, Wrocław 2007, p. 105 and 128-129. 


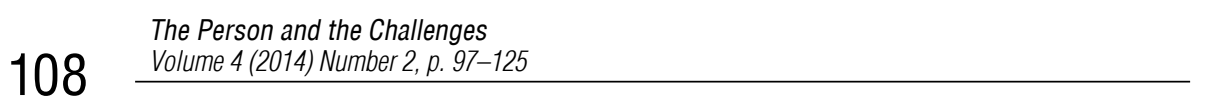

Bożena Szaynok, the Polish historian of the modern history after 1945, suggests defining 'usefulness' (produktivizatzye) as a change of the employee structure among the Jewish society. Thus in the post-war Jewish community in Poland a new type of Jewish worker became visible. However, in Poland, the term 'usefulness' was connected not only to the Jews but also to groups such as Gypsies and nuns, as well as to the idea of resettlement and the developing of Lower Silesia. The term 'produktivizatzye' was well-known in post-war Jewish and Polish newspapers. Szymon Zachariasz, the leader of the Jewish communists in Poland, wrote in one article published in 'Dos Naye Lebn' (A New Life): "We are not Jews from the diaspora anymore, nonuseful, without any roof over the head, new [people] coming from bunkers and camps". This slogan became a part of the conflict about the image of the Jewish history. There was a goal to change the attitude of work among the Jewish society. This would seem to be positive and, in many ways, a method of finding new strength through a fresh image, especially when the past carried so many negative connotations. This was to be applauded. However, to risk losing one's identity, or a society's identity, is a hazardous proposition at best.

\section{Jacob Egit - 'A New Jewish Man' and the Chairman of the Jewish Community in Lower Silesia}

Lower Silesia, after 1945, in the Jewish leaders' consideration, presented the best territory to create 'a new man' - a 'useful' Jew. In post-war Poland, Jews were supposed to be like the other normal societies in the world. 'Produktivizatzye' seemed like a way towards the 'normality'.

Jacob Egit was born in 1908 in Borysław (today Ukraine) in a religious Jewish family. At sixteen he joined the Poaley Zion Left party and became an active member of this political ideological movement. In 1930, he met some people who invited him to some communist meetings. That same year he left Poaley Zion Left and became a communist ${ }^{21}$. When the war between Germany and the Soviet Union began, Egit escaped with his wife and son to Kazakhstan. There he was working as a labourer for the soviets. In 1944, he came back to Lviv with the Soviet Army. Similar to many other Jews who survived the Holocaust in the Soviet Union, he felt that he should work

${ }^{21}$ B. Szaynok, Ludność żydowska na Dolnym Ślasku 1945-1950, Wrocław 2000, p. 5. 
towards communism. Even if those people experienced the worse part of the communist system in the Soviet Union they had the conviction that Russia saved their lives. In April 1945, Michał Mirski, a journalist and communist who worked for the Central Committee of Jews in Poland, asked Egit to cooperate with the Jewish Committee in Warsaw. In that time, after the Holocaust, Egit became a Jewish communist in Poland as a member of the Polish Workers' Party 22 .

Jacob Egit's decision to stay in Poland and rebuild the Jewish community is, in my opinion, connected to the concept of the 'new Jewish man'. Straight after the Holocaust he believed that only through a collective effort would it be possible to rebuild Jewish society. Egit worked as a leader and manager in the pre-war period. During the war he controlled the work of the workers' group in Kazakhstan. After World War II he wanted to work for the Jewish community in a leading position. Egit was in relatively good condition; he was physically healthy and he did not experience the Holocaust by himself. The psychological strength helped him take the chief position in the Jewish Committee in Dzierżoniów. I think that his membership with the communist party was helpful as well.

Since the beginning of the Jewish Settlement in Lower Silesia in May 1945, Jacob Egit was involved in the organizational work. He provided notes from meetings and events; in fact, later, he used it as background for his book 'Tzu a nay lebn' published in Wrocław in 1947 and his memoir 'Grand Illusion' published in Toronto in 1991. Jacob Egit, as a 'new Jewish man', convinced that there is a future for the Jewish community in Poland, published a number of articles in the Lower Silesian newspapers in Polish and Yiddish which where titled 'Zayt bagrist!' (Greetings to the inhabitants!). In those articles, Egit presented the possibilities for the newcomers as well as the current successes of the Jewish society in Lower Silesia. In his texts he emphasized optimistic reports about Polish and Jewish relations between 1945-1947.

In fact, the Jewish origin for many settlers was a source of real problems. A report from 25th July 1945 produced by the local Jewish Committee from Dzierżoniów for the Central Committee of Jews in Poland presented the Polish administration as highly anti-Semitic. The general situation in this report is different from the positive picture depicted in Egit's articles.

22 J. Egit, Grand illusion, Toronto 1991, p. 32; According to Egit, Mirski knew him before the war. In fact, many communist members of the Central Committee of Jews in Poland knew each other. 


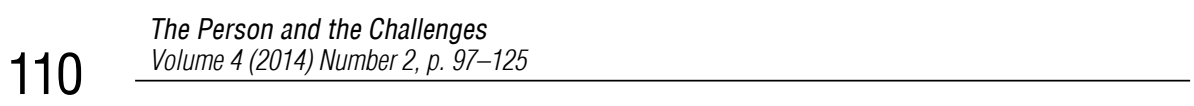

"Jews lived with the constant fear of expulsion, and in fact, in some places, civil servants tried to displace Jews /Rychbach-Dzierżoniów/. Even a few days ago a civil servant was threatening an ex-prisoner of the concentration camp in Ludwiksdorf. (...) Workers could get only $160 \mathrm{~g}$ bread daily which is not enough. Jewish canteens did not exist. In Ludwiksdorf, in the concentration camp barracks, 50 Jewish women and Germans live in five bedroom apartments. (...) It often happens that the civil servants are not directing Jews to the workshops, small factories and shops. And not long ago an official gave to the Jews a slaughterhouse and then he took it back and gave it to some Poles ${ }^{23}$ ".

Egit created himself as a carer and protector of the Jewish community in Lower Silesia. He was responsible for what, today, we call 'public relations'. He popularized Lower Silesia in the international press. In spite of it, he invited many famous people to visit the new Jewish settlement in Poland. Among those who came were the Jewish poet Itzik Manger and Molly Picon who was a well-known star in Hollywood.

In 1947, some members of the People's Workers Party wrote an anonymous note to the Central Committee of Jews in Poland saying: "Jacob Egit is a megalomaniac. In relation to the other members of the People's Workers Party he is unfriendly. Moreover, he is friends with people of dubious morality and highly uncertain pasts ${ }^{24}$.

Jacob Egit became a main figure of the Jewish community after World War II, as well as a symbol of Jewish life in Lower Silesia.

\section{Between hope and fear: 1946-1948}

A stabilization period for the Jewish settlement began in autumn of 1946 . The softening of emigration rules and the closure of the Polish borders in the winter of 1947 helped Jews fully concentrate on the Jewish life in Poland. At that time, political, social, economic and cultural activities continued to be carried out on a large scale. In 1946, 16,960 Jews were registered in Wrocław. However, the operation of the settlement, which began together with the arrival of the repatriates, was hindered by the emigration of the Jews

${ }^{23}$ State Archive in Wrocław, Wydziat Spoteczno-Polityczny, Sign. VI/269.

${ }^{24}$ B. Szaynok, Ludność żydowska na Dolnym Ślasku 1945-1950, Wrocław 2000, p. 144; also The State Archive in Wrocław, Polska Partia Robotnicza, sign. 295-IX-407. 
from Poland in summer of 1946. The main cause of this action was Kielce Pogrom on $4^{\text {th }}$ July 1946.

The atmosphere for migration had been prevailing among the Jewish population much earlier, yet after the Kielce Pogrom the public feeling penetrating communities was to leave Poland. This was especially visible in the territory of Lower Silesia. At the time, almost half of the settled population left Poland. Undoubtedly, the fact that Jewish emigration was directed via the Lower Silesia region, which was according to the agreement signed in July 1946 between the Polish government and Zionists' party that the government would not punish Jews for escaping from Poland, encouraged the Jews from this area to emigrate. In 1948, after the pogrom in Kielce and the difficulties with work places and housing, the number of the Jewish settlers was $12,580^{25}$.

The softening of feelings towards emigration and the closure of the border in winter 1947 began the period of maintenance. Newcomers were finding jobs mainly in the Jewish Cooperatives which were started up, i.e. in Wrocław 'Zgoda' (Peace) by 11-12 Ruska Street, 'Solidarność' (Solidarity) by Stalin's Street 35 and others, among them: 'Warszawianka' (Warsaw), 'Remont' (Refreshment). At the time, political, social, economic and cultural activities were carried out on a large scale. Ideas of creating an autonomous region for Polish Jews appeared. Simultaneously though, the events relating to Palestine and the future Jewish state, together with the political changes in Poland, had a greater impact on the situation of the Jews. They were questioning their independence and the preservation of Jewish character in the activities of their communities. This was clearly noticeable in the Lower Silesian region.

In the first years after the war, the government gave considerable autonomy to those who were involved with the reconstruction of Jewish life in Poland. The functioning of that little community had, in practice, no bearing on the problem that was most important to the communists: preserving and strengthening their stronghold on political power in Poland. Hence, initially, the authorities allowed them to reconstruct the majority of the Jewish political parties that had existed before the war. They did not interfere with Jewish religious life, cultural activities or education.

In August 1948, in Wrocław, a historic event took place. This was the First International Peace Conference after World War $\mathrm{II}^{26}$ to demonstrate against

${ }^{25}$ B. Szaynok, Ludność żydowska na Dolnym Ślasku 1945-1950, Wrocław 2000, p. 85.

${ }^{26}$ B. Szaynok, Ludność żydowska na Dolnym Ślasku 1945-1950, Wrocław 2000, p. 67. 
war. The aim was to declare the need for the preservation of peace in the world, so that the culture and nations could be saved from the catastrophe of another war. Delegates came from all over the world. Amongst them there were many prestigious figures, i.e.: Joliot Currie, Pablo Picasso, Aldous Huxley, William Groper, Uri Sul, Jorge Amado, Julian Tuwim, Len Schiller, Dov Chomsky, Ilya Ehrenburg and more. Despite the fact that this conference was organized in cooperation with the communist government, it did not issue a declaration or program about the future of the Jewish Settlement in Lower Silesia. However, in the world newspapers there were many comments and descriptions of the Jewish Settlement in Lower Silesia.

After this event, in autumn 1948, the Polish government drastically changed its policy towards the Jews. Communists began closing down Jewish institutions. This process started with closing down Zionist, 'Bund', and the other independent parties. It was clear, that, from this moment, the process of 'communization' of Jewish society began. In 1949 and 1950, the Jewish community in the Lower Silesian region experienced many significant changes. On the one hand, after the establishment of the State of Israel, Jews saw a new facilitation of emigration. On the other hand, the communist government in Poland started a new policy towards the Jewish minority, inspired by Stalin's policy in the Soviet Union. The fear of the government decision dramatically changed the character of Jewish settlements in the region. Institutions and organizations, as well as any activities, independent of Jewish communists were subjected to liquidation. A new organization, namely Social and Cultural Society of the Jews (Towarzystwo Społeczno-Kulturalne Żydów), was set up in Poland. It was created within Jewish communities, carrying out many activities among Jewish society and also represented many political parties.

During the height of the Stalinist period, 1948 to 1953, Jewish schools were nationalized. Aid from the West was also blocked. This had been a vital source for the Jewish organizations impoverished by the war. In October 1956 the Central Committee of Jews in Poland was shut down. This institution was particularly needed the domains of public health and education. The Social and Cultural Society of Jews in Poland was created instead, a society subordinated to the communist party. In December 1950, the frontiers were closed for Jewish emigration.

The Jewish Settlement in Lower Silesia began its decline in 1950. In the spring of 1950 the leader of the Jewish community, Jacob Egit, moved from Wrocław to Warsaw, where he was employed in a publishing house 'Yiddish 
Book'. In 1953, Egit was accused of trying to turn the Yishuv ${ }^{27}$ in Lower Silesia into Israel. These accusations were strongly connected with the process from 1952 in Moscow when Stalin's soldiers killed Jewish intellectuals, artists, writers, poets and actors. Egit's arrest and imprisonment under the Polish communist regime, for nine months, closed the last chapter of the Jewish settlement in Poland.

\section{Repatriates from the Soviet Union in Lower Silesia}

The change of the borders for many people in Eastern Europe, in practice, undermined resettlement. In July 1945, the Polish government made the decision about the repatriation of Polish citizens from the Soviet Union. Shortly after World War II, 1.2 million pre-war Polish (including Jews) citizens were repatriated to Poland from the eastern territories, annexed by the Soviet Union in $1945^{28}$. Overall, almost three million people were resettled from the Soviet Union to Poland and from Poland to Germany as a result of the government's repatriation ${ }^{29}$.

The emigration policy of the Soviet Jewry, as well as the other nations, in the first three years after the end of the World War II was indeterminate. Article 129 of the Soviet Union' Constitution from 1936 guaranteed asylum to "foreign citizens persecuted for defending the interests of the working people, or for scientific activities, or for struggling for national liberation" 30 but did not have a provision applying to the right of emigration for Soviet citizens. Although emigration was never explicitly recognized by the Stalinist government as a 'right' between 1945 and 1947, it was not expressly prohibited or prosecuted. However, during the years immediately after the war we can observe the re-awakening of the Jewish identity among the Jewish society in

27 Hebrew, settlement

${ }^{28}$ K. Kersten, Forced Migration and the Transformation of Polish Society in the Postwar Period, in: Redrawing Nations: Ethnic Cleansing in East-Central Europe, 1944-1948, Ed. P. Ther and A. Siljak, Lanham 2001, p. 80.

29 J. Kochanowski, Gathering Poles into Poland: Forced Migration from Poland's Former Eastern Territories, in: Redrawing Nations: Ethnic Cleansing in East-Central Europe, 1944-1948, Ed. P. Ther and A. Siljak, Lanham 2001, p. 138.

${ }^{30}$ USSR, Sixty years of the Union 1922-1982: A Collection of Legislative Acts and Documents, Ed. M. Georgadze, "Progress Publishers" (1982), p. 256. 
the Soviet Union ${ }^{31}$. The Soviet government did not make any serious attempt to be against their departure since it was part of the repatriation agreement negotiated between Poland and the Soviet Union.

According to the records from the Central Committee of Jews in Poland, at the beginning of January 1945 there were about 10,000 Jews living in newly liberated Poland ${ }^{32}$. The scholar Paul Glikson noted that until June 1945 about 61,000 Jews were registered in the Jewish Committees in Poland, including 13,000 in active military service ${ }^{33}$. In January 1946 the number of registered Jews reached 106,000 and six months later in June 1946, it peaked at $260,000^{34}$.

The journey back to Poland in the summers of 1944 and 1945, and in the first half of 1946, during the repatriation from the USSR, was very difficult for refugees. The trains were badly overcrowded and slow. The majority of Jewish returnees had no money to buy a ticket and have a seat, which was mostly a wooden bench. Moreover, anti-Semitism, especially in 1946, was a serious problem for returning Jews. They were afraid that the passengers, knowing their background, would react with anti-Semitism. In fact, trains in Poland were often a place of brutal attacks against Jewish passengers ${ }^{35}$.

Thousands of people came into the Lower Silesian Committees. It is important to stress the period of repatriation - the first half of 1946. Roughly speaking, half the Jews repatriated from the Soviet Union were directed to the Lower Silesian region. At the time of repatriation the number of Jews in the territory had increased to almost two hundred thousand. In spite of the fact that some of the repatriates treated Poland as a transit country, being determined to abandon Poland, constantly looking for the opportunity to leave the country,

${ }^{31}$ See more: S. W. Baron, The Russian Jew under Tsars and Soviets, New York 1987, p. 199; L. Kochan, The Jews in Soviet Russia since 1917, Oxford 1972.

${ }^{32}$ J. Adelson, W Polsce Zwanej Ludowa, in: Najnowsze Dzieje Żydów w Polsce w Zarysie do 1950 Roku, Ed. J. Tomaszewski, Warszawa 1993.

${ }^{33}$ P. Glikson, Jewish Population in the Polish People's Republic, 1944-1972, in: Papers in Jewish Demography, Jerusalem 1977, p. 237-38. Compare to J. Adelson, W Polsce Zwanej Ludowa, in: Najnowsze Dzieje Żydów w Polsce w Zarysie do 1950 Roku, Ed. J. Tomaszewski, Warszawa 1993.

${ }^{34}$ P. Glikson, Jewish Population in the Polish People's Republic, 1944-1972, p. 234.

${ }^{35}$ D. Engel, Patterns of Anti-Jewish Violence in Poland, 1944-1946, "Yad Vashem Studies" (1998) no. 26, p. 74. Also The Committee of Jews in Poland collected reports on anti-Jewish violence on trains, especially between September and December 1946. See: The Jewish Historical Institute, the Special Commission, sign. 15/087. 
they still created a substantial group and settled down in over 40 places of the Lower Silesian region. In spring 1946, the Central Committee of Jews in Poland directed 124 trains with 86,536 Jews ${ }^{36}$ to Lower Silesia. They created Jewish committees, which existed only temporarily in some cases, political representations, established schools and cultural institutions, as well as social and guardian institutions. For the international Jewish representatives coming over to Poland from abroad, as well as for the Polish Jews, the very region gave a peculiar impression, namely that the reconstruction of the Jewish lifestyle after the extermination seemed possible. Unfortunately, the Jewish Committees were unprepared for such a high number of new settlers. Lack of clothing, food, housing and money left a strong negative impact on the Jewish society. During spring 1946, 5,000 new immigrants were arriving, sometimes as often as every day. In July 1946, almost half the number of the Jews, who inhabited Poland at that time, was living in the Lower Silesian region.

The Jewish settlers shared the difficulties of the new life with the Poles. However, in contrast to the official, heroic images of the newcomers in the territory, the memoirs of the repatriates from the USSR - not only Jews but everyone who was coming from the Soviet Union - often told a different story from that presented in Bronisław Eidler's collection of photography ${ }^{37}$. However, the Jewish immigrants experienced problems unknown to Polish society. Police who were waiting for the trains with repatriates bit the Jews in a brutal and aggressive way. They also often called them using anti-Semitic words ${ }^{38}$. Sometimes, newcomers were welcomed with the words: "We need some Hitler back!"39.

On the one hand, the relation between Poles and Jews after the World War II was very difficult and complicated. On the other hand, there was the problem presented in the relations between settlers. For the Poles who settled in Lower Silesia, the Russian Jews were unwelcome and remained unwanted. Often they did not speak Polish. For many, their languages were Yiddish as well as Russian. The Polish press started to publish articles against them

${ }^{36}$ The Jewish Historical Institute Archive, Wydziat Ewidencji i Statystyki, sign 474.

${ }^{37}$ See: Wolność, 15 XII 1945, nr 6, E. Kaszuba, Między propagandą a rzeczywistościa. Polska ludność Wrocławia w latach 1945-1947, Warszawa-Wrocław 1997.

${ }^{38}$ B. Szaynok, Ludność żydowska na Dolnym Ślasku 1945-1950, Wrocław 2000, p. 67-69.

39 „Sprawozdanie z delegacji służbowej do Ścinawy i Kamieniogóry w dniach 1-5 VII 46 celem przyjęcia i urządzenia transportu z Taszkientu (ZSRR)" the train number: 7466 . The document is in private archive of Henryk Robak. 
creating a strong negative atmosphere. Most of them emigrated as soon as it was possible.

Besides all of these difficulties, the waves of new comers to Lower Silesia were constant. In April 1946 there were 40,000 new settlers and in July 1946 even 82,000 ${ }^{40}$. However, after the Kielce Pogrom, most of the Jewish immigrants used Lower Silesia only as a temporary place on the way to the Western countries, i.e. Germany, France, USA. The last train from the Soviet Union to Poland came in May 1959. But most of the repatriates were Poles.

\section{The Jewish Theatre in Lower Silesia}

The history of the post-war Jewish theatre in Lower Silesia began on the $17^{\text {th }}$ June 1945. That day, during the first conference of the Jewish Committees in Lower Silesia in Dzierżoniów, a concert and performance was organized. Actors on this event were survivors of Gross-Rosen concentration camp and its branches, located in Lower Silesia, as well as new-coming immigrants who had begun to settle in Lower Silesia. The concert was organized by Ruth TaruKowalska. Taru Kowalska (1926-1938) was an actress from the Theatre of Ida Kaminska between1926 and1938. She survived the war in Kazakhstan and returned to Poland in 1945. The program of this cultural event included Jewish, Polish as well as Russian songs, and a public reading of the poetry works of I. L. Peretz, Sh. Alejchem, J. Tuwim and B. Szenwald. In fact, the performance and concert were addressed to the Jewish and Polish audience.

The amateur movement among Jewish society constituted one of the main factors of Jewish culture development after 1945. Huge numbers of theatrical groups were active in almost all centers of the Jewish settlement. However, the amateur groups did not present high art. None of them had a whole play in its repertoire. Therefore, the Lower Silesian Jewish community created a professional troupe and ensured funds for its existence, as well as to supplement their repertoire. In fact, a professional Lower Silesian Jewish Theatre, including the group from Dzierżoniów, was formed during the Convention of Jewish Theatres' Artists, which took place in Łódź, 16-17 $7^{\text {th }}$ July $1946^{41}$. During this

\footnotetext{
${ }^{40}$ B. Szaynok, Ludność żydowska na Dolnym Ślasku 1945-1950, Wrocław 2000, p. 49.

${ }^{41}$ M. Bulat, Prasa polska a teatr jidysz w Polsce (1947-1956) - parawany dialogu. Część I: Wypisy ze świata pozorów, in: Nusech Pojln. Studia z dziejów kultury jidysz w powojennej Polsce,
} 
conference it was established that Zalman Kolesnikow became the director of the Jewish Theatre in Lower Silesia. Jewish artists in Poland decided to create a Theatrical Council and Jewish Theatre in Łódź. This theatre, formed from the group from Katowice, was directed by Moyshe Lipman ${ }^{42}$.

Why did Jewish settlers in Lower Silesia need a theatre? Jacob Egit, in his book Tzu a nay lebn, wrote that the theatre played a therapeutic role among the Jewish society after the Holocaust ${ }^{43}$. People needed to think about something other than World War II, the Holocaust and the suffering. In 1946, some artists ready to start work came aboard the trains from the Soviet Union to Lower Silesia. Zalman Kolesnikow and Chayele Rosenthal began to organize, in Wroclaw, a professional Jewish theatre in Lower Silesia. These two actors gathered together a numbers of artists and created the first group called 'Shiraim'. Simkhe Natan, the Jewish actor from Warsaw, famous for his theatre performances in Yiddish, led this group. 'Shiraim' included a list of actors famous for their pre-war plays: Grysha Ariel, Kety Efron, Zofia Gorlicka, Renia Glikman, Bina Gudes, Josef Griminger, Icchak Krelman, Zalman Kolesnikow, Lejb Lorner, Adolf Liberman, Dora Przepiorko and Jakov Reinglas. The first play was directed by Zalman Kolesnikow. It was a comedy written in Yiddish 'Where do you get a minyan?' ('Vu nemt men a minyan?'). The troupe presented this show for the patients in a sanatorium in spring $1946^{44}$. For survivors of the Holocaust, gathered in the sanatorium in Piotrolesie, it was very important to watch a performance presented in Yiddish and played by Jewish actors. In 1946 the troupe prepared an evening program of "The Jewish Humor and Laughter Night" in Wroclaw. It was an open event for everyone, not only for Jews, but the jokes were presented in Yiddish. The themes of the plays were usually optimistic. Directors of the Jewish Theatre in Lower Silesia and actors tried to create as much fun as possible, with much laughter to help people to get through the post-Holocaust trauma. They helped Jewish and Polish audiences, for one moment, to forget about the recent tragedies of the Holocaust and World War II. A ceremonial premiere for the Jewish Theatre in Lower Silesia took place on the $8^{\text {th }}$

Ed. M. Ruta, Kraków Budapeszt 2008, p. 101-127.

${ }^{42}$ About the history of the Jewish theatre in Poland after the Holocaust see: J. Wróbel, $W$ cieniu Holocaustu. Odrodzenie społeczności Żydowskiej w Łódzkiem po II wojnie światowej, „Biuletyn Instytutu Pamięci Narodowej” (2005) no. 11(58).

43 J. Egit, Grand illusion, Toronto 1991, p. 47.

${ }^{44}$ J. Egit, Grand illusion, p. 48. 
December 1946 during the First Conference of Jewish Cultural Activists in Lower Silesia. During this event, the Jewish theatre performed a play 'The Bloody Joke' ('Der blutiker shpas') written by Sholem Aleykhem.

The building for the Jewish theatre became a subject of many discussions. The lack of its own place for rehearsals and performances for the group was a serious problem. In 1946, when the Lower Silesian Jewish Theatre officially started their performances, the biggest problem was the lack of venues. Since the theatre constituted the favorite entertainment of the Jewish community, it became the matter of general interest. Zionists did not support the development of a theatre since they perceived their stay in Poland as temporary. The Orthodox Jews, also, were not interested in the Jewish theatre as it was not 'a kosher place'. Those two groups did not support the idea of building a Jewish theater in Lower Silesia, which would be located near Świdnicka Street in Wrocław. Notwithstanding these difficulties, at the beginning of 1947, at a meeting of the Provincial Jewish Committee it was finally decided that one of the basic tasks of the Jewish community would be finding a place for Lower Silesian Jewish Theatre. A special board was formed. It was supposed to collect some donations for this purpose. One of the actions, which they had initiated, was gaining some additional funds from the Jews employed by various Cooperatives in Wrocław. Their funds were obtained by the deduction of $1 \%$ of wages of Jewish employees employed by various Cooperatives. Among others were the Tailor's Cooperative "Zgoda" in Wrocław and Olgin's Shoemaker's Cooperative in Wrocław. Also, nonJewish employees declared in their will to donate $1 \%$ of their wages for the construction of the Jewish theatre buildings. Twelve million zlotys were collected over the period of half a year. The Zionists were not satisfied by this huge success. Zionists thought that collection of money for this purpose was improper, when Jews were fighting in Palestine. In fact, they conducted an anti-theatre campaign of the kind stating that "every penny spent for the theatre was wasted since Jews were not going to stay in Poland anyway and the theatre would be nationalized and would not serve the Jews (...) ${ }^{945}$. However, they were not successful in their rhetoric. Despite the Zionists, the Jewish community remained enthusiastic and kept supporting the idea of creating a Jewish theatre in Lower Silesia. Those people who could not

${ }^{45}$ See Jidiszer Jiszewin Niderszlezje. Żydowskie Osiedle na Dolnym Śląsku, Ed. J. Harbanowicz, J. Lisek, Wroclaw 2006, p. 6. 
financially support the construction of the theatre helped by manual work. In consequence, collective effort, the unique involvement of the whole community, the hard work and sacrifice resulted in a wonderful result.

The opening ceremony of the Jewish Theatre building in Świdnicka Street, 28 in Wrocław took place on the $2^{\text {nd }}$ April 1949. The building was given the name of 'Estera Rachela Kamińska', the mother of Jewish theatre. Its auditorium had 500 seats and the stage was equipped with modern technical facilities. According to the report in "Mosty" (1949 no 55): "After the cutting of the ribbon by citizen Provincial Governor, the guests toured a beautiful and perfectly technically equipped theatre building, which shall become the main cultural center of the Jewish community of Lower Silesia in the future." During the opening ceremony the play Wandering Stars ('Blondsherne shtern') was performed, written by Sholem Aleykhem and directed by Zygmunt Turkow.

In December 1946 Simkha Natan passed away. Ida Kamińska was asked to fill his position. Kaminska's theatre, during the period of construction, performed approximately 250 times in many towns of Lower Silesia, in Upper Silesia (Katowice, Sosnowiec, Bielsko, Bytom, Gliwice) as well as in Łódź, Warsaw, Szczecin and Wrocław. The theatre group prepared premieres without a professional stage. The actors gathered in some places to practice without the knowledge of how it will look like on the scene. Until the end of summer of 1948 it conducted a tour around Lower Silesia using the trucks of the Provincial Jewish Committee. In September 1948, the group received a bus from the Central Office of Production Cooperatives "Solidarity" for the theatre needs.

The audience of the Lower Silesian Jewish Theatre was always interested in the plays performed there, mainly in Yiddish. Moreover, even the Poles who didn't know Yiddish used to attend. In a short time, the Lower Silesian Jewish Theatre was well-known as a popular venue, a theater for everybody. In their memoirs, the actors complained about babies crying during the plays, children running around the auditorium, toddlers crawling, babbling and trying to climb to the stage. The adult audience also behaved loudly. The acts were loudly commented on, some viewers shouted, waved their hands or even ate and drank ${ }^{46}$. Often it was really hard for the actors to perform. This behavior certainly originated from the pre-war habits. The roots of this

${ }^{46}$ K. Rajtar, Powojenny Wroctaw ,ziemia niczyja” $i$,mała ojczyzna”, in: Ich małe ojczyzny. Lokalność, korzenie, tożsamość w warunkach przemian, Ed. K. Rajtar, Wrocław 2003, p. 195. 
behavior stemmed from the past habits of open-air theatres or among the Jewish audiences even earlier, from the Purim Shpil performances ${ }^{47}$.

In the years of 1946-1949 the theatre hosted 14 premieres. The plays were directed by Ida Kamińska, Zygmunt Turkow and many others. The repertoire was not uniform - apart from ambitious plays, there were also entertainment performances, vaudevilles and variety shows. In order to satisfy the various tastes of its broad audience, the Jewish theatre also had to fulfill different functions. The repertoire of Lower Silesian Jewish Theatre was also characterized by a great diversity of styles and genres. Jewish culture had been developing freely and directors had a carte blanche with regard to repertoire selection. This situation lasted until 1949.

In the Lower Silesian theatre there dominated, initially, classical adaptations of Jewish writers' works - Jakub Gordin, Abraham Goldfaden and Sholem Aleykhem. The public demanded plays showing the non-existent world of Jewish folklore, song and customs - the world of the shtetls. Under pressure of the authorities, critics began to the demand inclusion of works concerning modern problems into the theatre repertoire. Each cultural center was obliged to implement socialist realism principles to all fields of life. Not only Jewish but also Soviet, English and Polish plays began to appear in the repertoire from then on. A new phase of the theatre activity began, moving it away from the so-called eclecticism, formalism and martyrdom tendencies allegedly characteristic in post-war Jewish art and towards the socialist realism doctrine.

In fact, the Jewish theatre was nationalized on the $21^{\text {st }}$ September 1949 and Szeftl Zak became its director. The ideas of creating an autonomous region for Polish Jews in the territory appeared. Simultaneously with the process of nationalization, the events relating to Palestine and the future Jewish state together with the political changes in Poland started to have a growing impact on the situation of the Jews. With the restrictions placed on the Jewish character in the activities of their communities they started to question their independence.

Despite the influence of the communism policy towards the national Jewish art, the most famous play of Lower Silesian Jewish Theater was The Dream of Goldfaden (Goldfaden kholem) directed by Jakub Rotbaum. It

\footnotetext{
${ }^{47}$ About the history and nature of the Purim Shpil see: N. S. Doniach, Purim, or the Feast of Esther: An Historical Study, Philadelphia 1933.
} 
was performed on the $25^{\text {th }}$ February 1950 . The scenography was designed by Aleksander Jędrzejewski and Wiesław Lange, two great Polish designers regularly cooperating with the theatre, with costumes by Jadwiga Przeradzka. It was a musical: a fantasy constituted of Jewish writers' texts - Ainbinder and Fencter and fragments of Goldfaden's comedy Sorceress adapted by Itzik Manger. But the prologue, epilogue, as well as parts of the texts were written by Jakub Rotbaum. He also created a scenario in which characters from various plays appear and interact with each other in various configurations. Rotbaum's adaptation showed the situation of a Jewish theatre in America falling into hands of a swindler-director, Hopke. In order not to become involved in conflict with the authorities over the arrest of a young actor, Markus, who participated in an African American demonstration, the director decides to stage a different play than previously planned - a not very ambitious operetta. This outraged the whole troupe, especially the old prompter, Oyzer. The following part of the play is Oyzer's dream - various characters from several of Goldfaden's plays appear and become embroiled in strange relations and situations. The action revolves around the problem of finding and freeing Markus. Oyzer wakes up in the final scene and refuses to cooperate with director, Hopke, and leaves, with the rest of the group, to create a real theatre, which will stage plays really wanted by the public. The Dream of Goldfaden enchanted Jewish as well as Polish audiences. As the critic of "Gazeta Robotnicza", Jan Kott wrote: "It was probably the best stage production I have seen in Wrocław. It was an attempt at the reconciliation of reality with an unreal world comparable in style to the best Shakespearian fantasies of the kind (...) a theatrical thing not only charming but also full of profound social values" (1950 no 70$)^{48}$. The play was staged several times not only in Poland but also all over the world.

Jakub Rotbaum ${ }^{49}$ is a most forgotten Jewish director, actor and painter, who was very famous for his modern and brave theatre. He remained abroad in the years of 1938-1949 and returned to Poland in September of 1949 because of a special appeal from Ida Kamińska. Rotbaum began his work at the Lower Silesian Jewish Theatre with the permission of the Ministry of Culture and Art. In a publication commemorating the 25th anniversary

${ }^{48}$ B. Szaynok, Ludność żydowska na Dolnym Śląsku1945-1950, Wrocław 2000, p. 15.

49 A. Hannowa, Jakub Rotbaum: Świat zaginiony; Malarstwo, rysunki, Wrocław 1995. Published in Polish, German and English. 
of the National Jewish Theatre in the Peoples' Republic of Poland, Jakub Rotbaum recalls that he wanted to participate in a rebuilding of the country: "I thought that I could do it in the most useful way, by doing what I knew best. I accepted the offer to take the post of artistic director of the Lower Silesian Jewish Theatre, located in a new building in Wrocław". The first premiere he prepared was Montserrat by Emmanuel Robles, performed under the title of The Great Struggle.

From 1951 to 1962, he directed Teatr Polski in Wrocław, where he staged famous productions of plays by Stanisław Wyspiański, Bertolt Brecht, Nikolai Gogol, and Shakespeare. After 1968 he directed only Yiddish theatre in Poland as well as in Europe, the Americas, and Australia. Rotbaum's last production was in Warsaw in 1985: Sholem Aleykhem's The Winning Lottery Ticket ${ }^{50}$.

On the day of January 1, 1950, two independent theatres - Łódź Jewish Theatre and Lower Silesian Jewish Theatre - were merged into one institution called The National Jewish Theater with a seat in Wrocław. However, during the same year, in May, its name was changed at the order of the Minister of Culture and Art, Stanisław Dybowski, to The National Jewish Theatre in Łódź. In spite of this decision, two autonomous artistic troupes, in Wroclaw and in Łódź, were still maintained. Just as before, even though under joint leadership of Ida Kamińska, separately prepared premieres took place. The theatres conducted extended traveling activity and visited each other. It is an interesting point that, for greater productions, such as 'Blank Family' in 1950, the actors from Łódź, as well as from Wrocław were hired. In 1953 Wrocław again became an informal base of the theatre and in 1955 the National Jewish Theatre was given a new seat in Królewska Street in Warsaw. Since then, all premieres were staged by the visiting group from the capital, in the building in Wrocław. Estera Rachela Kamińska Jewish Community Centre, where celebrations, meetings and concerts took place, was also located here.

All of this activity, with creative decisions being reached by multiple sources and spirited individuals, is irrefutable evidence that the community was coming together, bonding, acting as one. The actors, writers, directors and producers, not to mention, the not inconsiderable participation of the public themselves, shows a society putting aside troubles and differences,

${ }^{50}$ See also: Sz. Gąssowski, Państwowy Teatr Żydowski im. Ester Rachel Kamińskiej: Przeszłość i teraźniejszość, Warszawa 1995. 
artistic temperaments and strong personalities, building something tangible and good from the ashes of destruction and horror. The history of theatre in Lower Silesia is a vital part of its potential re-birth.

\section{Epilogue: The Twilight of the Jewish Settlement in Lower Silesia}

In a short period after World War II, Lower Silesia appeared to be a relatively safe area for Jews compared with other areas in Poland. However, even here, it was possible to hear some anti-Semitic comments about quasi-heroes from ghettos in public transport which passed the Ghetto Heroes Square ${ }^{51}$. The Jewish Settlement in Lower Silesia called in Yiddish press in the whole world. The 'Yidisher Yishuv' in Nidershlezye was chosen as the centre for Jewish settlement and designated as the 'Jewish Revival Movement'. The leaders of this project, Jacob Egit and people around him, were convinced that it was a place in which they could succeed in renewing the Bundist's ideas of the Jewish national and cultural autonomy. In addition to this, they wanted to stem the emigration of the Holocaust survivors.

Cultural development was deemed essential for the renewal of Jewish life in Lower Silesia, simultaneously with the wave of the Jewish repatriates from the Soviet Union. The Yiddish culture, due to its secular and popular nature, was considered an asset and was to play an integral role in the movement. In 1946 the Jewish Association for Culture and Art (JACA) was founded to coordinate Jewish cultural life. By the end of 1947, it had organized thirtythree libraries, thirteen cultural centres, five choruses and five orchestras. A small publishing house 'Nidershlezye' was also set up to print Jewish books as well as two weeklies, 'Nidershlezye' in Yiddish, and 'Nowe Życie/Dos Naye Lebn' (New Life) in Polish and in Yiddish. Moreover, the Jewish secular education provided in Yiddish and Hebrew was possible until 1949. The last Hebrew school in Lower Silesia was closed in 1950 in Bielawa.

Together with the process of the nationalization of the Jewish institutions in Poland, the Jewish community in Lower Silesia lost the illusion of the possibility for cultural autonomy in the post-war Poland. In my opinion, Jacob Egit's dream about the Jewish community in Poland failed with the Kielce Pogrom.

${ }^{51}$ Z. Lauban, Wrocławski antysemityzm, „Nowe Życie”, no 4, 17 $7^{\text {th }}$ February 1947. 
In conclusion, the promising idea of the Jewish Settlement in Lower Silesia initially successfully developing, eventually failed for several reasons. Firstly, it is important to stress the lack of effective organization and the ubiquitous post-war chaos ${ }^{52}$. Also, for many Holocaust survivors, an important fact was that plenty of Germans were still living in Lower Silesia. The process of the deportation of German civilians, as mentionedearlier, took a very long time and ended only in 1957. However, many Jews in Lower Silesia saw this new reality only as a temporary solution. Some of them never unpacked their suitcases, convinced that at some point, Lower Silesia could return to Germany. Nevertheless, the news about Kielce Pogrom and the anti-Jewish violence did not help the Lower Silesian community believe in the bright future of Jews in Poland. In 1948, together with the establishment of the State of Israel, the Zionist party convinced a huge part of the Jewish society to leave Poland. This was even easier because of Stalin's policy against the Jewish nation in the Soviet Union. The murder of Solomon Mikhoels, a famous Jewish director and actor from the Moscow State Theatre, is usually considered to be a turning point in the history of Soviet and Eastern European Jewry. It also marked the transition to a policy of official antiSemitism. His death was followed by the closure of most Jewish institutions in the Soviet Union and Poland, including schools, Jewish Committees and JAC. By 1949-1950 all independent social, cultural and educational activity of the Jewish community had been shut down by the communist government. This lack of perspective forced Jewish society to continue emigrating from Poland. Although there was a brief revival of Jewish life in Lower Silesia, which took place with the arrival of the last wave of repatriates from the Soviet Union in 1957 and 1958, it never rose to the same level of cultural development as it was in 1946-1948. State anti-Semitism, highly visible in the Polish press and the general government policy in 1967 and 1968, led to even more emigration, leaving approximately 3,500 Jews in Lower Silesia. The infamous March 1968, in a great majority of historical literature, marked the symbolic end of the post-war Jewish life in Poland.

${ }^{52}$ In 1946 in Wrocław there were only 677 police officers. 


\section{Bibliography}

Aleksiun N., Dokad dalej? Ruch syjonistyczny w Polsce (1944-1950), Warszawa 2002.

Bronsztejn S., Z dziejów ludności żydowskiej na Dolnyn Śląsku po II wojnie światowej, Wrocław 1993.

Egit J., Grand illusion, Toronto 1991.

Hurwic-Nowakowska I., Żydzi polscy (1947-1950): analiza więzi społecznej ludności żydowskiej, Warszawa 1996.

Michlic J. B., Poland Threatening Other: The image of the Jew from 1880 to Present, London 2006.

Nalewajko-Kulikov J., Obywatel Jidyszlandu. Rzecz o żydowskich komunistach w Polsce, Warszawa 2009.

Nowak A., Historia jednej sceny, ,Notatnik Teatralny” (2009) nr 56-57, p. 374-379

Novik P., Oyrope: tzvishn milkhome un sholem rayze-bilder, batrachtungen, New York 1952.

Ordyłowski M., Życie codzienne we Wrocławiu 1945-1948, Wrocław 1991.

Shlomi H., The Communist in the Central Committee of Jews in Poland, November 1944-February 1947, Gal-Ed 1992, v. 13, p. 287-331.

Szaynok B., Ludność żydowska na Dolnym Śląsu 1945-1950, Wrocław 2000.

Żydzi i komunizm, Ed. M. Bilewicz, B. Pawlisz, Warszawa 2000. 